\title{
Well-Being from Governmental Interventions -A Look at Copreneurship in Power Looms of Karnataka
}

\author{
Shivakami Rajan, Hariharan Ravi, P. Muralidharan \\ Department of Commerce, St. Joseph's College of Commerce (Autonomous), Bangalore, India \\ Email: shivakami.rajan@gmail.com
}

How to cite this paper: Rajan, S., Ravi, H., Muralidharan, P. (2019) Well-Being from Governmental Interventions-A Look at Copreneurship in Power Looms of Karnataka. Journal of Service Science and Management, 12, 639-648.

https://doi.org/10.4236/jssm.2019.125044

Received: July 3, 2019

Accepted: August 16, 2019

Published: August 19, 2019

Copyright $\odot 2019$ by author(s) and Scientific Research Publishing Inc. This work is licensed under the Creative Commons Attribution International License (CC BY 4.0).

http://creativecommons.org/licenses/by/4.0/

\begin{abstract}
Purpose of Paper: This study investigates the well-being of Copreneurship in power looms of Karnataka in a rural context. It highlights the well-being in terms of the satisfaction that the couple experience in entrepreneurship within the rural copreneurial environment arising from the usage of Governmental Interventions. It further compares this feeling of well-being with couples who do not make use of Governmental interventions. Design/Methodology/Approach: The objective of this study is to contribute to the study of entrepreneurial wellbeing, specifically focusing on rural Copreneurship and Government. The methodology of this study is comparative where the primary objective is to investigate the overall personal well-being of ecopreneurs who have utilized governmental interventions in comparison with ecopreneurs who did not utilize Governmental interventions and support. Findings: The data confirm a positive relationship between usage of governmental interventions and the perceived overall well being of high users amongst the ecopreneurs. The results supported the hypothesized relationship between overall wellbeing and high copreneurial usage of governmental interventions. Furthermore, they found that high user Copreneurs are more satisfied with the pleasure that business gives them even if their business achievements (profit, sales, and revenues) are not as per expectation. Research Limitations: As the research is limited to rural copreneurial couples in power looms of the textiles industry in MSMEs of Karnataka state of India only; the findings may limit in application to urban ecopreneurs. Practical Implications: Results of this study revealed that having identified governmental interventions and using them was associated with greater perceived satisfaction. Original/Value of Paper: The results for efficiently expected to be encouraging usage of governmental interventions purpose.
\end{abstract}




\section{Keywords}

Copreneurial Wellbeing, Governmental Interventions, Life Satisfaction, Overall Wellbeing

\section{Introduction}

India, an Asian Continent, being the seventh-largest country in terms of area is multilingual and multi-ethnic with a population. On its part, the Indian Government considers entrepreneurship as a measure of remedial intervention. Rightly so, since entrepreneurship is argued as the most appropriate vehicle for socio-economic growth accelerating development and improving the quality of life of its population by many researchers. As India lives in its villages, rural development is paramount to national development. Indian rural entrepreneurship is largely in the form of self-employment in family business-the unsung heroes of the Indian Economy [1]. The Indian textiles industry-the largest employers in India is one of the traditional industry catering to the employment needs next to the agriculture industry and accounts for 13 percent of the total. Handloom, power-loom, handicrafts, hosiery, knitting, and sericulture are many of the largest players in this unorganized industry. Employment opportunities in this sector are both self-employment and employment.

This study seeks to understand and explore the impact of governmental interventions on the overall personal wellbeing as perceived of the ecopreneurs in the rural textiles sectors of Karnataka State. Such information's will aid other similar rural members to start similar ventures, thereby increasing the quantum of the family business in rural areas mitigating the rural unemployment issues by using the Governmental interventions specifically meant for them. This methodology of this study is comparative-where the primary objective is to investigate the overall personal well-being of ecopreneurs who have utilized governmental interventions in comparison with ecopreneurs who did not utilize Governmental interventions and support. The central premise of this study is that ecopreneurs experience personal wellbeing as a result of the nexus of enterprising ecopreneurs \& valuable Governmental initiatives. Thus, expected that on the adoption of Governmental schemes, initiatives, the ecopreneurs would experience overall personal well-being with high levels of satisfaction. In particular, suggested that the more Governmental support a copreneurial couple utilizes, the more the feeling of overall personal well-being experienced by them when compared to those who do not make use of Governmental support.

The uniqueness of copreneurial well-being in rural context has today become one of the most discussed fields in rural startup-entrepreneurship. Critical analysis of disassociation and discontinuance of rural businesses because of perceived failure is required to understand the efficient usage of governmental interventions. Limited research has investigated this unique state of being of co- 
preneurs in the rural context.

This study attempts to add incrementally to literature in three ways. Firstly limited research has investigated this unique concept of well being of copreneurs in a rural context. Not to mention, there is hardly any literature on copreneurs in a rural context so that this study would be the first contribution on copartnership in a rural context, specifically on the concept of the well-being of rural copreneurs. Secondly, due to the numerous disassociation and discontinuance of rural businesses because of perceived failure, critical analysis is required to understand the efficient usage of governmental interventions, spurting policy matters. Finally, on examination of the relationship between copreneurial wellbeing, governmental schemes, and its outcomes, this study uses responses from both the users of governmental schemes and non-users of governmental schemes for desired outcomes. Thus by identifying the antecedents of copreneurial wellbeing, this study contributes to policymaking efforts that seek to increase the copreneurial ventures and decrease discontinuances of rural business ventures.

Hence a need is realized to take up this investigation to access the role of governmental schemes in copreneurial wellbeing. The empirical setting selected is the district of Anekal in the state of Karnataka in India. The specific objective of this study is to investigate the copreneurial role in the outcomes of their business, the individual factors, the external influence of governmental factors. It suggests that copreneurial wellbeing arises not only from the coprneurial individual efforts and ability but also from the usage of governmental schemes in a given context. This paper is on 119 copreneurs selected from Anekal District engaged in power loom sector of the traditional textiles industry, using convenience sampling method.

The main limitation of this study is that the results apply to Anekal and thus might not be valid for other regions which are not textiles based. Moreover, our study does not consider the individual contributions of the copreneurial couple and the education level of the couple. Hence future studies on determinants of copreneurial well-being could test the result of this study in another context.

The rest of the paper is as follows. The following text section explains the entrepreneurial context of India, specifically so of the textiles industry of Karnataka and the schemes, measures offered by the Government to the entrepreneurial players of textiles Industry in the section called focus of the study. It is followed by a detailed discussed on the theoretical background of the study. The objectives of the study, the methodology adopted to test the hypothesis developed is discussed, followed by results/discussion, future consideration, and implications.

\section{Theoretical Background}

In rural Indian, entrepreneurial ventures are of these nature-Copreneurship ventures. These Copreneurship ventures are a subset of a family business, where husband and wife are joint decision-makers of the business. They have to face 
the challenge of balancing personal and professional relationship, i.e. romantic and professional life. Areas, where significant research have found in Indian context traditional, are on success, challenges, and succession planning business [2]. In management literature, employee well-being as a motivator for enabling successful organization has been well-researched and documented. In entrepreneurial literature, interventions of microfinance support to entrepreneurs have shown to increase and enhance the personal well-being of the entrepreneur [3]. Various literatures acknowledges that the entrepreneurial success of business run by couples, nevertheless scant literature talks about copreneur's well-being based on the dynamics of governmental interventions in the rural context [4]. The literature connecting well-being and corpreneurship in Indian Industry is relatively absent. Exploring this connection would throw light upon a critical understanding of what Governmental interventions impact entrepreneurial well-being, how the ecopreneurs achieve this, and what effect it has on their business.

\section{Objectives}

Understand the influence of governmental interventions on the ecopreneurs overall personal well-being.

Analyze the relationship between selected interventions and copreneurial overall personal well-being.

\section{Methodology}

\section{Research Problem}

In the absence of research studies in the context of overall personal wellbeing associated with Governmental support systems and policies among rural ecopreneurs, this research is exploratory.

\section{Sampling Techniques}

Data for this chapter are from a sampling frame list provided by the District Industries and Commerce Department (DIC) of Karnataka, from which 119 ecopreneurs were selected from rural areas, using convenience sampling method. A questionnaire-based survey used which was completed using a face-to-face interview from ecopreneur couples of active manufacturing, wholesale, retail, and textile-related MSMEs.

The questionnaire consisted of six sections. The first section questions were related to the business profile of the respondents, the second focussed on the demographic profile of the ecopreneurs, while the third and fourth contained questions related to their personality (10 items) and business pleasure \& achievement (25 items). Questions of the copreneurs perception of their overall satisfaction (17 items) from undertaking business were in the fifth section.

\section{Data and Variables}

The Department of Industries and Commerce (DIC), Government of Karnataka, established in 1913, is one of the oldest institutions set up by the Govern- 
ment of Karnataka. This department oversees the industrial development of the state. It houses the regional and district centers in all districts of the state of Karnataka. The regional centers manage the district database of all entrepreneurs registered under their ambit. The data of registered entrepreneurs of Bengaluru Urban District are from the State DIC, Bangalore.

\section{Measures}

Statistical Package for Social Science was used to test the hypothesis applying Exploratory Factor Analysis, Multiple Regression Analysis.

\section{Hypothesis}

$\mathrm{H}_{0}{ }^{1}$ : there is no difference between the perceived overall well-being of high users of Governmental schemes and the perceived overall wellbeing of low users of Governmental schemes.

$\mathrm{H}_{0}{ }^{2}$ : Governmental interventions have a significant positive relationship with the overall well-being of Copreneurs.

\section{Results}

In this section, the results of the analysis reflect the validity and reliable of the instrument are first to present followed by the demographic profile of the respondents.

Validity and Reliability: Two tests of validity for the questionnaires content validity and construct validity are used to test the extent of generalization of the results out of the casual analysis to another variable-content validity with the opinion of the subject experts in addition to the judgment of the author. The intercorrelations of the scale items of each construct was a substantially high inferring similarity of measure of each construct, thereby confirming the convergent validity of all the measures of the study. The Cronbach alpha value (Table 1) of all the measures taken for the study gave a result above 0.70 , indicating strong internal consistency among the variables of each measure.

Majority of the ecopreneurs were more than 40 years old (57 percent of the ecopreneurs). Around 60 percent of the ecopreneurs used the family funds to start their ventures while only 17 percent of ecopreneurs used their funds to start their ventures, 23 percent used borrowed funds or took loans to set up their business. Likewise, 40 percent felt that business-in-the-family was the most important factor that helped them in their business, while 60 percent felt that this did not influence their business decisions in any way. Most of the businesses surveyed were relatively seasoned with either business-aged between 6 - 10 years (44 percent) or more than 10 years (14 percent). Among the businesses aged between 6 - 10 years, 52 percent were manufacturing, or production and textiles sales (retail and wholesale) dominated both 6 - 10 years and more than 10 years businesses (16 percent and 18 percent) respectively as shown in Table 2.

Table 3 shows that among the seasoned-copreneurs, 55 percent had an average business turnover in the range between Rs. 50,000 to Rs. 100,000 and 28 percent had average business turnover between Rs. 100,000 - Rs. 500,000, whereas among the copreneurs with business aged more than 15 years, 75 per- 
cent of them had an average business turnover of Rs. 50,000 to Rs. 100,000 and 25 percent had an average business turnover of Rs. 100,000 - Rs. 500,000.

Exploratory factor analysis of the proactive personality to identify the underlying factor structure done after confirmation of the adequacy of the sample size and test of fitness using Bartlett's test of sphericity and Kaiser Meyer-Olkin (KMO) measure of sampling adequacy. It gave a KMO measure of sampling adequacy of 0.830 (greater than the threshold value of 0.60 indicating that the number of samples was adequate for conducting factor analysis and Bartlett's test showed significance implying that the correlations between the various items of measure are not zero or by chance. The factor analysis extracted two factors and was named using the using a causal naming process as forwarding-looking for factor- 1 and Change-Doer for factor-2. The test-retest procedure for the two new factors showed a reliability Cronbach's coefficient of 0.886 and 0.682 , respectively.

Table 1. Cronbach values of measurement scales.

\begin{tabular}{cccc}
\hline Construct Name & Mean & Standard Deviation & Reliability Coefficient \\
\hline Proactive personality & 33.08 & 6.403 & 0.885 \\
Business Pleasure \& Achievements & 85.29 & 9.157 & 0.836 \\
Overall Life Satisfaction & 61.73 & 8.272 & 0.887 \\
\hline
\end{tabular}

Source: primary data computed.

Table 2. Business sector wise and business age wise distribution.

\begin{tabular}{|c|c|c|c|c|c|c|}
\hline \multirow{2}{*}{\multicolumn{2}{|c|}{ Particulars of Business }} & \multicolumn{4}{|c|}{ Bus Age Range } & \multirow{2}{*}{ Total } \\
\hline & & 1 - 5 Years & $6-10$ Years & $11-15$ Years & $>15$ Years & \\
\hline \multirow{5}{*}{ Sector } & Trading & 0 & 7 & 0 & 16 & 23 \\
\hline & Production/Manufacturing & 0 & 28 & 1 & 0 & 29 \\
\hline & Spinning & 1 & 6 & 0 & 1 & 8 \\
\hline & Textiles & 0 & 12 & 16 & 31 & 59 \\
\hline & Total & 1 & 53 & 17 & 48 & 119 \\
\hline
\end{tabular}

Source: primary data computed.

Table 3. Business age-wise with business turnover.

\begin{tabular}{cccccc}
\hline \multirow{2}{*}{ Particulars of Business Turnover } & \multicolumn{4}{c}{ Age-Wise Distribution } \\
\cline { 3 - 6 } & $0-50,000$ & $6-10$ Years & Percentage & $>15$ Years & Percentage \\
\hline $\begin{array}{c}\text { Buss } \\
\text { Turnover }\end{array}$ & $50,000-100,000$ & 29 & 4 & 0 & 0 \\
& $100,000-500,000$ & 15 & 28 & 36 & 75 \\
& Above 500,000 & 7 & 0 & 12 & 25 \\
& Total & 53 & 100 & 48 & 100 \\
\hline
\end{tabular}

Source: primary data computed. 
All the copreneurs surveyed utilized at least two governmental schemes in their business. Initially, an analysis was carried out to find out if Governmental schemes usage (yes $=1$, no $=2$ ) is independent of the awareness of the Government schemes among the coprenuers (yes $=1$, no $=2$ ). A $\chi^{2}$ (chi-square) test conducted comparing the frequencies of usages with the frequencies of awareness, and a significant interaction $(p<0.5)$ between the awareness of the government schemes and the usage of the governmental schemes for all the schemes considered for the study.

Multiple Linear (MLR) study is used to test the hypothesis for both high users and low users of Governmental interventions. The independent variable Business achievement and Business pleasure (Continuous variable) and the dependent variables considered for the studies are the overall personal wellbeing (Continuous variables).

\section{Impact on Overall Satisfaction-High Users of Governmental Schemes}

Among the 119 copreneurs surveyed, about 23.5 percent were found to be high users of Governmental schemes. Multiple regression analysis was used to test for the high users of Governmental schemes and if the business achievements \& pleasure significantly predicted corpreneurs' ratings of overall wellbeing. The adjusted $\mathrm{R}$ square value obtained 0.740 explains the 74 percent relationship exists among the variables. The F statistic-value is 39.449 , indicating a significant overall relationship between the dependent variables and the independent variable (Table 4).

The coefficient of determination $\left(R^{2}\right) 0.759$ indicated that 75.90 percent of the variance change in overall personal wellbeing of high-users of governmental schemes is a result of business achievement and business pleasure. The adjusted $\mathrm{R}$ square value of 0.740 explains that the 74 percent relationship exists among the variables. The F statistic-value (39.449) indicates a significant overall relationship between the dependent variables and the independent variable.

The results of the regression indicated the two predictors explained $75.90 \%$ of the variance $(\mathrm{R} 2=0.759, \mathrm{~F}(2,25)=39.449, \mathrm{p}<0.005$ (Table 5). The Coefficient describes the coefficient of each independent variable (business pleasure, business achievement) effect on the dependent variable (overall personal wellbeing) for high-users. The un-standardized coefficients disclose the expected change in overall personal wellbeing of the high users with one unit increase in the independent variable (business achievement and business pleasure).

Of the two explanatory business predictors (business achievement and business pleasure), only on predictor business pleasure (significant at 5 percent) is found statistically significant in influencing the overall wellbeing indicating that high user Copreneurs are more satisfied with the pleasure that business gives them even if their business achievements (profit, sales, and revenues) are not as per expectation. Hence, the impact of the relationship can explain with the help of the following equation:

Overall Satisfaction $=0.701+0.906 *$ Business Pleasure [High Users] (1)

This paramount finding is consistent where the self-employed persons are 
Table 4. Model summary of MLR (high users of governmental schemes).

\begin{tabular}{ccccccc}
\hline Model & $\mathbf{R}$ & $\mathbf{R}^{2}$ & F Value & $\mathrm{df}_{1}$ & $\mathrm{df}_{2}$ & Sig. \\
\hline 1 & 0.871 & 0.759 & 39.449 & 2 & 25 & $(0.000)^{\star *}$ \\
\hline
\end{tabular}

${ }^{*}$ Sig at 0.01 percent level. Source: computed from primary data.

Table 5. Beta coefficients of MLR (high users of governmental schemes).

\begin{tabular}{|c|c|c|c|c|c|c|}
\hline & \multirow{2}{*}{ Model } & \multicolumn{2}{|c|}{ Unstandardized Coefficients } & \multirow{2}{*}{$\begin{array}{c}\text { Standardized Coefficients } \\
\text { Beta }\end{array}$} & \multirow{2}{*}{ t Value } & \multirow{2}{*}{ Sig. } \\
\hline & & B & Std. Error & & & \\
\hline \multirow{3}{*}{1} & (Constant) & 0.701 & 0.372 & - & 1.885 & 0.071 \\
\hline & Bus Ach Mean & -0.024 & 0.146 & -0.027 & -0.164 & 0.871 \\
\hline & Bus Pleasure Mean & 0.906 & 0.169 & 0.893 & 5.364 & 0.000 \\
\hline
\end{tabular}

more satisfied with their job because of greater autonomy, flexibility, skill utilization, and high perceived job security, including the ability to pursue self-initiatives. It also echoes' the activities of business impact both economic and personal well-being of the business owner positively.

\section{Impact on Overall Satisfaction-Low Users of Governmental Schemes}

Among the 119 copreneurs surveyed, 74.5 percent were low users of the Governmental schemes; the MLR generated a statistically significant model ( $\mathrm{p}<$ 0.005 ) which held the most predictive overall personal wellbeing variables for the low-usage group.

The results of the regression for low-users indicated the two predictors explained $77.70 \%$ of the variance $\left(\mathrm{R}^{2}=0.770, \mathrm{~F}(2,88)=147.032, \mathrm{p}<0.005\right)($ Table 6).

For the low-users of Governmental Schemes, both business achievement and business pleasure are significant at 5 percent, interestingly enough, the constant is negative (-0.592). This unexpected and important result indicate that Copreneurs who are low users of Governmental schemes do not experience overall personal wellbeing when business achievement and business pleasures are absent. Business achievements and business pleasures are significant positive predictors of overall personal wellbeing for low user copreneurs. This study reveals that the supporting role of large or private institutions plays a vital role in ensuring business success and subsequently improves the wellbeing of the entrepreneurs, thus reducing the local community's poverty. Between the two positive independent predictors, the highest influencing factor is a Business pleasure $(0.848)$ with business achievement $(0.382)$ as the second most influencing variable. The standardized beta coefficients explain the order of importance of the independent variables taken to determine the impact on the dependent variable, showing that business pleasure is more important than business achievements. The result can explain with the help of the following equation:

Overall Satisfaction $=-0.592+0.848$ * Business Pleasure +0.382 *

Business Achievement [Lower Users] (2) 
Table 6. Model summary of MLR (Low users of governmental schemes).

\begin{tabular}{ccccccc}
\hline Model & $\mathbf{R}$ & $\mathbf{R}^{2}$ & F Value & $\mathrm{df}_{1}$ & $\mathrm{df}_{2}$ & Sig. \\
\hline 1 & 0.877 & 0.770 & 147.032 & 2 & 88 & $(0.000)^{* *}$ \\
\hline
\end{tabular}

${ }^{*}$ Sig at 0.01 percent level. Source: Computed from primary data.

This equation can be applied to estimate how much overall satisfaction a copreneurial couple could be expected to achieve based on the amount of business achievement they gain and the business pleasure they derive by being in business.

Both types of copreneurs-Forward-Looking and Change-Doer have found to use Governmental schemes in the study areas. At the time of the study, there were eighteen Governmental schemes available for rural copreneur in the textiles industry with the number of copreneurs who utilized them.

\section{Findings}

The schemes related to interest subsidy, new-unit loans, seed margin, marketing, MSME-MDA (Marketing Assistant Division), Location in EP-Zone (Export Promotion Zone), R \& D, IT and Industrial Park assistance not utilized by more than 85 percent of copreneurs and its respective association with business satisfaction is found to be insignificant again indicating it is not considered a positive requirement for business growth. It could be that since all of these are having a cost-based impact in business, it is insignificant.

Not surprisingly, loans, marketing, and R \& D are found to be signs indicating that copreneurs considered utilizing them even if it impacted their business growth, as it mitigated constraints that interfere with their personal life enabling to experience life satisfaction. This finding collaborates with the findings that copreneurs generally dispel the myth of separate domains of family and work, implying that finances between business and personal household.

\section{Conclusion and Implication}

This study attempted to find out the level of influence of Governmental interventions on the wellbeing of the copreneurial couple in Textile industry in Karnataka. All the copreneurial participants of the study area did use at least two Governmental schemes, but only the high users of schemes experience overall satisfaction and well being when compared to no or low users. Interestingly among the high users, the business achievement did not matter much more than the being in business experiencing business pleasure $(\mathrm{p}<0.05)$ unlike business achievements $(p>0.05)$ surprisingly, indicating that copreneurs experience well being and satisfaction just being in business. Work and business can bring in much more pleasure to enterprising couples. The high user's respondents were satisfied with the governmental support schemes. Thus Government interventions, supports, and schemes can move the individual wellbeing of copreneurs to next level. Not only their business pleasure increases but overall wellbeing in- 
creases. Governmental support schemes give an opportunity to increase the feeling of wellbeing as well as increase the business achievement return from their business for the copreneurial couple. One factor that needs further study is the need to look at the right timing of the usage of Governmental interventions.

\section{Conflicts of Interest}

The authors declare no conflicts of interest regarding the publication of this paper.

\section{References}

[1] Ackermann, S.J. (2012) Are Small Firms Important? Their Role and Impact. Springer Science \& Business Media, New York, NY.

[2] Sharma, P. and Rao, A.S. (2000) Successor Attributes in Indian and Canadian Family Firms: A Comparative Study. Family Business Review, 13, 313-330. https://doi.org/10.1111/j.1741-6248.2000.00313.x

[3] Dzisi, S. and Obeng, F. (2013). Microfinance and the Socio-Economic Wellbeing of Women Entrepreneurs in Ghana. International Journal of Business and Social Research, 3, 45-62.

[4] Fitzgerald, M.A. and Muske, G. (2002) Copreneurs: An Exploration and Comparison to Other Family Businesses. Family Business Review, 15, 1-16.

https://doi.org/10.1111/j.1741-6248.2002.00001.x 